\title{
Calcium Hydroxide Intracanal Dressing Removal with Different Rotary Instruments and Irrigating Solutions: A Scanning Electron Microscopy Study
}

\author{
Milton Carlos KUGA ${ }^{1}$ \\ Mário TANOMARU-FILHO ${ }^{1}$ \\ Gisele FARIA $^{1}$ \\ Marcus Vinicius Reis SÓ2 \\ Tiago GALLETTI ${ }^{3}$ \\ José Roberto Sampaio BAVELLO ${ }^{3}$ \\ ${ }^{1}$ Department of Restorative Dentistry, Araraquara Dental School, São Paulo State University, Araraquara, SP, Brazil \\ ${ }^{2}$ Departament of Endodontics, Federal University of Rio Grande do Sul, Porto Alegre, RS, Brazil \\ ${ }^{3}$ Private Practice, Santa Fé do Sul, SP, Brazil
}

\begin{abstract}
This study evaluated the efficacy of 2 types of rotary instruments employed in association with sodium hypochlorite (NaOCl) or EDTA in removing calcium hydroxide $(\mathrm{CH})$ residues from root canals dentin walls. Forty-two mandibular human incisors were instrumented with the ProTaper System up to F2 instrument, irrigated with $2.5 \% \mathrm{NaOCl}$ followed by $17 \%$ EDTA and filled with a CH intracanal dressing. After 7 days, the $\mathrm{CH}$ dressing was removed using 4 techniques: NiTi rotary instrument size 25, 0.06 taper (K3 Endo) and irrigation with 17\% EDTA (Group 1), NiTi rotary F1 instrument (ProTaper) and irrigation with 17\% EDTA (Group 2), NiTi rotary instrument size 25, 0.06 taper and irrigation with $2.5 \% \mathrm{NaOCl}$ (Group 3) and NiTi rotary F1 instrument and irrigation with $2.5 \%$ $\mathrm{NaOCl}$ (Group 4). Two roots without intracanal dressing were used as negative controls. Teeth were evaluated by scanning electron microscopy, in the cervical and apical canal thirds. None of the techniques removed the $\mathrm{CH}$ dressing completely. In the apical and cervical thirds, F1 instrument was better than instrument size 25, 0.06 taper in removing $\mathrm{CH}$ residues $(\mathrm{p}<0.05)$, regardless of the final irrigating solution. No difference was found between the irrigating solutions in the groups of F1 instrument and of instrument size 25 , 0.06 taper $(\mathrm{p}>0.05)$. The negative controls had no $\mathrm{CH}$ residues on the dentin walls. In conclusion, the ProTaper F1 instrument was better than K3 Endo instrument size 25, 0.06 taper in the removal of $\mathrm{CH}$ intracanal medication, regardless of irrigating solution used.
\end{abstract}

Key Words: calcium hydroxide, intracanal dressing, rotary instruments, sodium hypochlorite, EDTA.

\section{INTRODUCTION}

Presence of microorganisms in the root canal system plays a fundamental role in the pathogenesis of apical periodontitis $(1,2)$. The use of intracanal dressing to disinfect the root canal system has been advocated to enhance the success of root canal treatment (3-5). An ideal root canal dressing must have antimicrobial efficacy causing no harm to the periapical tissues. Hence, calcium hydroxide $(\mathrm{CH})$ has been considered to be the material of choice as an intracanal medicament (6).

However, if this medication is not completely removed, its presence on the dentin walls could compromise the endodontic treatment (7). Persistence of $\mathrm{CH}$ residues may interfere with sealing ability of endodontic sealers $(8,9)$, and affect the adhesion of endodontic sealers to the canal walls (10). Moreover, there is evidence that these residues may react with zinc oxide and eugenol-based cements, forming calcium eugenolate, which hinders the penetration of cement into the dentin tubules (8).

Some methods $(9,10)$ and/or irrigation substances (8) have been proposed for removal of $\mathrm{CH}$ dressing. Studies have showed that irrigation with sodium hypochlorite alone is not efficient to remove $\mathrm{CH}$ medication $(11,12)$. Alternatively, irrigation with EDTA and recapitulation of the instrumentation with the last file used in the apical preparation $(12,13)$ as well as the use

Correspondence: Prof. Dr. Milton Carlos Kuga, Departamento de Odontologia Restauradora, Faculdade de Odontologia de Araraquara, UNESP, Rua Humaitá, 1680, 14801-903 Araraquara, SP, Brasil. Tel: +55-16-3301-6391. Fax: +55-16-3301-6392. e-mail: miltoncarloskuga@hotmail.com 
of rotary instrument or ultrasonic points in conjunction with irrigation has been recommended $(11,14)$.

Considering the importance of the complete removal of intracanal dressing before root canal filling, this study aimed at evaluating the efficacy of 2 types of rotary instruments, in association with $\mathrm{NaOCl}$ or EDTA, in removing $\mathrm{CH}$ residues from root canal dentin walls, using scanning electron microscopy (SEM).

\section{MATERIAL AND METHODS}

After approval by the Research Ethics Committee (13/2010), 42 extracted human permanent mandibular central incisors measuring 19 to $21 \mathrm{~mm}$ in length, stored in $1 \%$ thymol solution, were obtained from the tooth bank for this study. After coronal access with a \#4084 diamond bur (KG Sorensen, São Paulo, SP, Brazil), the cervical third was prepared using S1 and SX instruments (ProTaper System; Dentsply Maillefer, Baillagues, Switzerland). The working length was established $1.0 \mathrm{~mm}$ short of the total tooth length and confirmed radiographically.

Biomechanical preparation of the root canal was performed with ProTaper System, under irrigation with $2.5 \% \mathrm{NaOCl}$, using the technique proposed by Guelzow et al. (7). All root canals were instrumented up to a $\mathrm{F} 2$ instrument and a final rinse with $5.0 \mathrm{~mL}$ of $2.5 \% \mathrm{NaOCl}$ and $5 \mathrm{~mL}$ of $17 \%$ EDTA (Biodinâmica, Ibiporã, PR, Brazil) solutions were performed. The solution was removed by aspiration (Navitip; Ultradent, South Jordan, UT, USA) and the canals were dried with paper points. Then, the canals were filled with a pasted of $\mathrm{CH}$ (Biodinâmica) propylene glycol (Científica, Santa Fé do Sul, SP, Brazil) at a powder to liquid ratio of 1:1 (15), using a lentulo spiral (Dentsply Maillefer). Radiographs were taken in mesiodistal and buccolingual directions to confirm complete filling of the root canals. The coronal access cavities were sealed with a layer of gutta-percha followed by Coltosol (Coltène, WhaleDent, Switzerland). All specimens were kept in a closed box, with the roots placed in moist environment for 7 days at room temperature. After this period, the coronal access was opened and the canal was irrigated with $5 \mathrm{~mL}$ of $2.5 \% \mathrm{NaOCl}$ solution.

Forty specimens were randomly divided into 4 experimental groups $(n=10)$, according to the rotary instrument and final irrigating solution used for removal of $\mathrm{CH}$ residues: G1- K3 Endo instrument size 25, 0.06 taper (Sybron Endo, Orange, CA, USA) and irrigation with 17\% EDTA, G2 - ProTaper F1 instrument and irrigation with 17\% EDTA, G3 - K3 Endo instrument size 25, 0.06 taper and irrigation with $2.5 \% \mathrm{NaOCl}$ and G4 - ProTaper F1 instrument and irrigation with $2.5 \% \mathrm{NaOCl}$. Canal preparation was performed using an electric engine (X-Smart; Dentsply Maillefer) with constant speed of $250 \mathrm{rpm}$ and rotational force of 1.6 $\mathrm{N} . \mathrm{cm}$, at the working length. The final irrigation was done with $5 \mathrm{~mL}$ of irrigating solution. Two roots without intracanal dressing were used as negative controls.

All substances were placed in sterile $10 \mathrm{~mL}$ syringes with a 30 -gauge needle, calibrated at working length with rubber stop. The solutions were aspirated with a green Navitip point (Ultradent), and dried with absorbent paper points.

Thereafter, grooves were prepared with a water-cooled diamond bur on the buccal and lingual surfaces and the teeth were split along their long axis in a buccolingual direction using a surgical chisel. For SEM analysis, the specimens were dehydrated, fixed on aluminium stubs, sputter-coated with gold, and examined with a scanning electron microscope at $10 \mathrm{kV}$ (JEOL, Tokyo, Japan). Magnification of $\times 1000$ was used to evaluate cleaning of the canal walls at the apical and cervical root canal thirds (5 and $10 \mathrm{~mm}$ from the apex, respectively). Three previously calibrated examiners evaluated the cleanliness of root canal walls, by assigning each specimen with the following scores: 0 - absence of residues, 1 - small amount of residues (up to $20 \%$ of the surface covered), 2 - moderate amount of residues (20\% to $60 \%$ of the surface covered), and 3 - large amount of residues (more than $60 \%$ of the surface covered). Figure 1 shows representative SEM micrographs of score attribution.

The obtained data were analyzed statistically by the nonparametric Kruskal-Wallis test and Dunn's post-test at a significance level of $5 \%$ using the BioEstat software.

\section{RESULTS}

None of the techniques removed the $\mathrm{CH}$ dressing completely. Table 1 shows scores and rank means of $\mathrm{CH}$ residues for each experimental group, in apical and cervical thirds of root canal. Table 2 shows the statistical comparison of groups. In the apical and cervical thirds, F1 instrument was more efficient than instrument size $25,0.06$ taper in removing $\mathrm{CH}$ residues $(\mathrm{p}<0.05)$, regardless of the final solution. No difference was found 

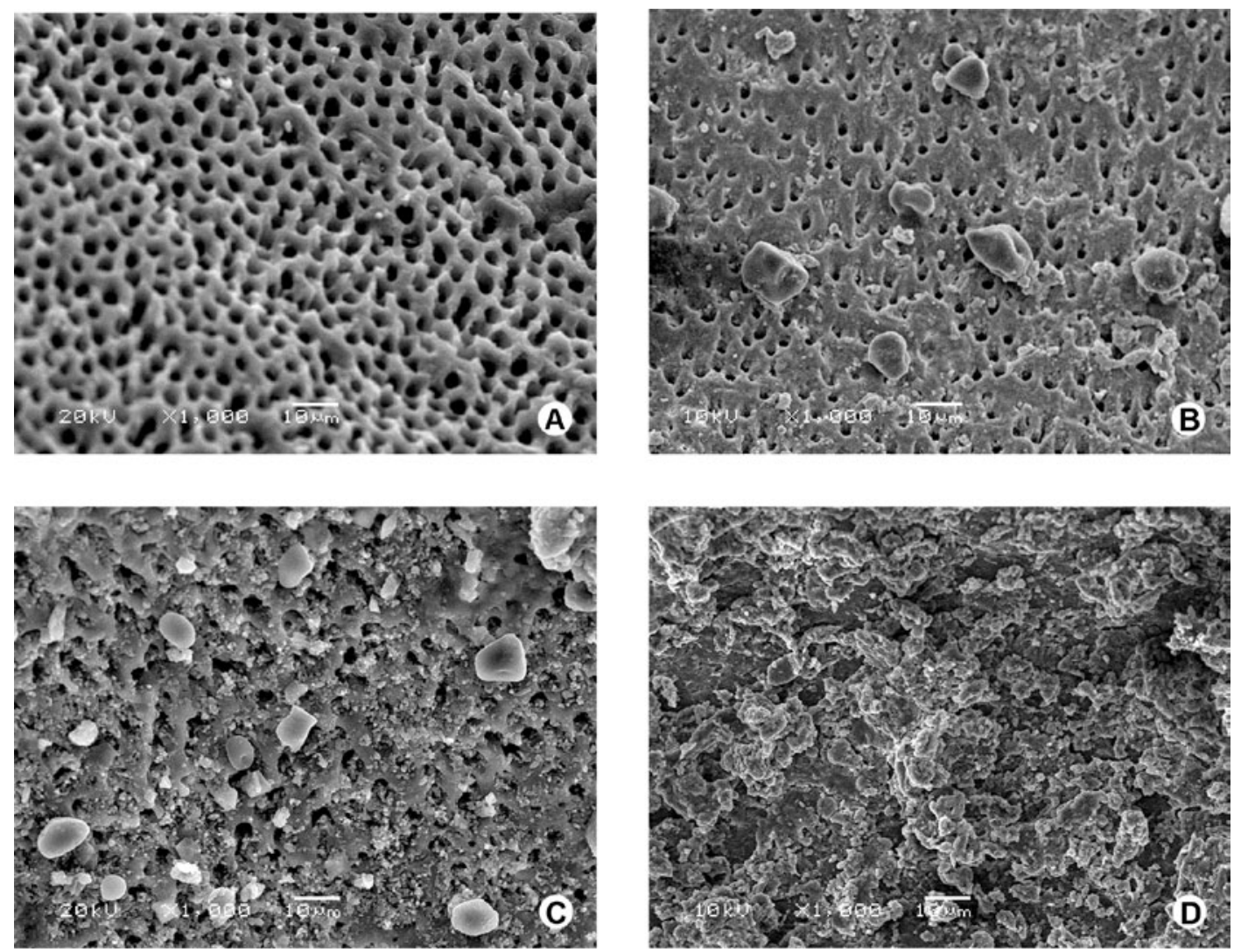

Figure 1. SEM images representative of scores attribution. $\mathrm{A}=$ Score 0 : absence of residues; $\mathrm{B}=$ Score 1 : small amount of residues; $\mathrm{C}=$ Score 2: moderate amount of residues and $\mathrm{D}=$ Score 3: large amount of residues.

Table 1. Score distribution and rank means in the groups, regarding the presence of $\mathrm{CH}$ residues at the apical and cervical canal thirds

\begin{tabular}{lccccc}
\hline \multirow{2}{*}{$\begin{array}{l}\text { Group/ } \\
\text { Third }\end{array}$} & 0 & 1 & 2 & 3 & Rank means \\
\cline { 2 - 4 } G1 & 1 & 2 & 5 & 1 & 30.20 \\
Apical & - & 1 & 3 & 6 & 29.55 \\
Cervical & & & & & \\
G2 & 8 & 2 & - & - & 11.70 \\
Apical & 5 & 4 & 1 & 0 & 10.50 \\
Cervical & & & & & \\
G3 & - & 8 & 2 & - & 26.80 \\
Apical & - & 1 & 4 & 5 & 28.45 \\
Cervical & & & & & \\
G4 & 7 & 3 & - & - & 13.30 \\
Apical & 3 & 4 & 3 & - & 13.95 \\
Cervical & & & & & \\
\hline
\end{tabular}

Table 2. Intergroup comparison regarding presence of $\mathrm{CH}$ residues on root canals walls at the apical and cervical thirds.

\begin{tabular}{|c|c|c|c|}
\hline Root canal third & Groups & $\mathrm{Z}_{\mathrm{obs}}$ & $Z_{\text {crit }}$ \\
\hline \multirow{6}{*}{ Apical } & $\mathrm{G} 1 \times \mathrm{G} 2 *$ & 3.3235 & 2.635 \\
\hline & G1 x G3 & 0.4412 & 2.635 \\
\hline & G1 x G4* & 3.0181 & 2.635 \\
\hline & $\mathrm{G} 2 \times \mathrm{G} 3 *$ & 2.9614 & 2.635 \\
\hline & G2 x G4 & 0.3138 & 2.635 \\
\hline & $\mathrm{G} 3 \times \mathrm{G} 4 *$ & 2.6476 & 2.635 \\
\hline \multirow{6}{*}{ Cervical } & $\mathrm{G} 1 \times \mathrm{G} 2 *$ & 3.7298 & 2.635 \\
\hline & G1 x G3 & 0.2104 & 2.635 \\
\hline & $\mathrm{G} 1 \times \mathrm{G} 4 *$ & 2.9839 & 2.635 \\
\hline & $\mathrm{G} 2 \times \mathrm{G} 3 *$ & 3.5194 & 2.635 \\
\hline & $\mathrm{G} 2 \times \mathrm{G} 4$ & 0.7460 & 2.635 \\
\hline & $\mathrm{G} 3 \times \mathrm{G} 4 *$ & 2.7735 & 2.635 \\
\hline
\end{tabular}

*Indicates statistically significant difference $(\mathrm{p}<0.05)$. 
$(p>0.05)$ between the irrigating solutions in the groups of F1 instrument and instrument size 25, 0.06 taper. The negative controls had no residues on the dentinal walls.

SEM images representative of $\mathrm{CH}$ residues in apical and cervical thirds of the experimental groups are shown in Figure 2.

\section{DISCUSSION}

K3 Endo and ProTaper systems are commonly used in endodontic treatment for cleaning and shaping root canals. ProTaper instruments are characterized by progressively increasing taper, a convex triangular cross-section, and a modified guiding tip. On the other hand, the K3 Endo system is a triple-fluted instrument with asymmetrical cross-section in combination with radial land relief, positive rake angle and a constant taper $(16,17)$.

The best results of ProTaper F1 instrument in relation to K3 Endo instrument size 25, taper 06 could be explained because the biomechanical preparation was performed with the ProTaper System and consequently the F1 instrument had a better adaptation than instrument size 25, 0.06 taper to the root canal walls. However, the instrument size 25, 0.06 taper has in D0 and D16 similar taper to $\mathrm{F} 1$ instrument. The possible difference between results in $\mathrm{CH}$ removal could be in function of design and the variable taper present in F1 instrument.

The removal of $\mathrm{CH}$ residues has been investigated using various products such as $\mathrm{NaOCl}$ and chelants to dissolve inorganic particles of the smear layer and intracanal medication $(9,18)$. EDTA-T is widely used as the best irrigant to remove the smear layer $(19,20)$. In a previous study, irrigation with $0.5 \% \mathrm{NaOCl}$ without use of instruments had the worst results of $\mathrm{CH}$ removal compared to other endodontic irrigants inclusive $17 \%$ EDTA-T (12). Roding et al. (13) using the master apical file and irrigation with different solutions showed that $20 \%$ EDTA performed significantly better than $1 \%$ $\mathrm{NaOCl}$ and water. The authors explain these results because $\mathrm{NaOCl}$ has limited ability to dissolve inorganic substances such as $\mathrm{CH}$. In present study no difference was observed between 17\% EDTA and $2.5 \% \mathrm{NaOCl}$ in the groups of F1 instrument and instrument size 25, 0.06 taper, showing that the type of final rotary instrument has more influence in $\mathrm{CH}$ removal than final irrigation substances, regardless of the third.

None of the techniques used in this study removed completely the $\mathrm{CH}$ from the root canals. This is in agreement with results of the previous studies, which showed the presence of $\mathrm{CH}$ debris on the root canal walls, regardless of the removal technique $(9,11,13,14)$.

Under the tested conditions of this study, it was concluded that ProTaper F1 instrument was more effective than K3 Endo instrument size 25, 0.06 taper in the removal of $\mathrm{CH}$ intracanal medication. The irrigating solutions used as a final rinse did not play an important role in the removal of $\mathrm{CH}$ residues from the dentin walls. Further studies should be undertaken with other techniques of root canal preparation and irrigating
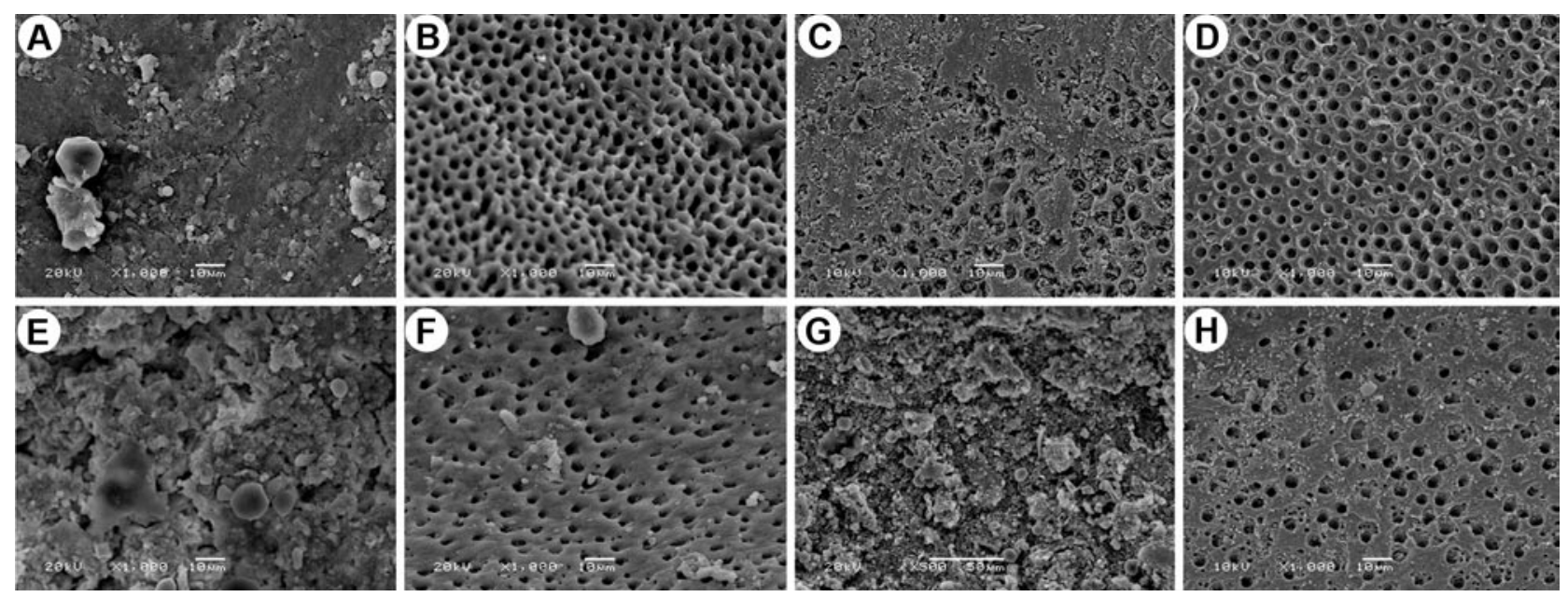

Figure 2. SEM micrographs representative of $\mathrm{G} 1$ ( $\mathrm{A}=$ apical third; $\mathrm{E}=$ cervical third $), \mathrm{G} 2(\mathrm{~B}=$ apical third; $\mathrm{F}=$ cervical third $)$, $\mathrm{G} 3(\mathrm{C}=$ apical third; $\mathrm{G}=$ cervical third) and $\mathrm{G} 4$ ( $\mathrm{D}=$ apical third; $\mathrm{H}=$ cervical third). 
solutions to evaluate the removal of intracanal dressing from the root canal walls.

\section{RESUMO}

O objetivo deste estudo foi avaliar a eficácia de dois tipos de instrumentos rotatórios em associação à irrigação com hipoclorito de sódio $(\mathrm{NaOCl})$ ou EDTA na remoção de resíduos de hidróxido de cálcio (HC) das paredes do canal radicular. Quarenta e dois incisivos inferiores de humanos foram instrumentados com o sistema ProTaper até o instrumento F2, irrigados com $\mathrm{NaOCl}$ a 2,5\%, seguido de EDTA a 17\% e preenchidos com medicação intracanal à base de HC. Após 7 dias, $\mathrm{o} \mathrm{HC}$ foi removido utilizando 4 técnicas: instrumento 25/0.06 (K3 Endo) e irrigação com EDTA a 17\% (Grupo 1), instrumento F1 (ProTaper) e irrigação com EDTA a 17\% (Grupo 2), instrumento 25/0.06 e irrigação com $\mathrm{NaOCl}$ a 2,5\% (Grupo 3) e instrumento $\mathrm{F} 1$ e irrigação com $\mathrm{NaOCl}$ a 2,5\% (Grupo 4). Duas raízes que não receberam medicação intracanal foram utilizadas como controles negativo. Foram avaliados os terços cervical e apical dos canais radiculares por meio de microscopia eletrônica de varredura. Nenhuma das técnicas removeu completamente a medicação à base HC. Nos terços apical e cervical, o instrumento $\mathrm{F} 1$ foi melhor do que o instrumento 25/0.06 na remoção dos resíduos de $\mathrm{HC}(\mathrm{p}<0,05)$, independentemente da solução irrigadora final. Não houve diferença entre as soluções irrigadoras nos grupos do instrumento $\mathrm{F} 1$ e do instrumento $25 / 0.06$ ( $\mathrm{p}>0,05$ ). Os controles negativos não apresentaram resíduos de HC nas paredes dentinárias. Concluiu-se que o instrumento F1 do ProTaper foi melhor que o instrumento 25/0.06 do K3 Endo na remoção da medicação intracanal à base de $\mathrm{HC}$, independentemente da solução irrigadora utilizada.

\section{REFERENCES}

1. Siqueira JR JF. Endodontic infections: concepts, paradigms, and perspectives. Oral Surg Oral Med Oral Pathol Oral Radiol Endod 2002;94:281-293.

2. Leonardo MR, Hernandez MEFT, Silva LAB, Tanomaru-Filho M. Effect of a calcium hydroxide-based root canal dressing on periapical repair in dogs: a histological study. Oral Surg Oral Med Oral Pathol Oral Radiol Endod 2006;102:680-685.

3. Byström A, Claesson R, Sundqvist G. The antibacterial effect of camphorated paramonochlorophenol, camphorated phenol and calcium hydroxide in the treatment of infected root canals. Endod Dent Traumatol 1985;1:170-175.

4. Grecca FS, Leonardo MR, Silva LAB, Tanomaru-Filho M, Borges MA. Radiographic evaluation of periradicular repair after endodontic treatment of dog's teeth with induced periradicular periodontitis. J Endod 2001;27:610-612.
5. Tanomaru-Filho M, Leonardo MR, Silva LAB. Effect of irrigation solution and calcium hydroxide root canal dressing on the repair of apical and periapical tissues of teeth with periapical lesion. $\mathrm{J}$ Endod 2002;28:295-299.

6. Carrotte P. Endodontics: Part 9. Calcium hydroxide, root resorption, endo-perio lesions. Br Dent J 2004;197:735-743.

7. Guelzow A, Stamm O, Martus P, Kielbassa AM. Comparative study of six rotary nickel-titanium system and hand instrumentation for root canal preparation. Int Endod J 2005;38:743-752.

8. Margelos J, Eliades G, Verdelis C, Palagias G. Interaction of calcium hydroxide with zinc oxide-eugenol type sealers: a potential clinical problem. J Endod 1997;23:43-48.

9. Lambrianidis T, Margelos J, Beltes P. Removal efficiency of calcium hydroxide dressing from the root canal. J Endod 1999;25:85-88.

10. Barbizam JV, Trope M, Teixeira EC, Tanomaru-Filho M, Teixeira FB. Effect of calcium hydroxide dressing on the bond strength of a resin-based endodontic sealer. Braz Dent J 2008;19:224-227.

11. Kenee DM, Allemang JD, Johnson JD, Hellstein J, Nichol BK. A quantitative assessment of efficacy of various calcium hydroxide removal techniques. J Endod 2006;32:563-565.

12. Salgado RJC, Moura-Netto C, Yamazaki AK, Cardoso LN, Moura AAM, Prokopowitsch I. Comparison of different irrigants on calcium hydroxide medication removal: microscopic cleanliness evaluation. Oral Surg Oral Med Oral Pathol Oral Radiol Endod 2009;107:580-584.

13. Rödig T, Vogel S, Zapf A, Hülsmann M. Efficacy of different irrigants in the removal of calcium hydroxide from root canals. Int Endod J 2010;43:519-527.

14. Balvedi RP, Versiani MA, Manna FF, Biffi JC. A comparison of two techniques for the removal of calcium hydroxide from root canals. Int Endod J 2010;43:763-768.

15. Estrela C, Holland R, Bernabé PF, de Souza V, Estrela CR. Antimicrobial potential of medicaments used in healing process in dogs' teeth with apical periodontitis. Braz Dent J 2004;15:181185.

16. Chianello G, Specian VL, Hardt LC, Raldi DP, Lage-Marques JL, Habitante SM. Surface finishing of unused rotary endodontic instruments: a SEM study. Braz Dent J 2008;19:109-113.

17. Dall'Agnol C, Hartmann MS, Barletta FB. Computed tomography assessment of the efficiency of different techniques for removal of root canal filling material. Braz Dent J 2008;19:306-312.

18. Foster K, Kuild J, Weller N. Effect of smear layer removal on the diffusion of calcium hydroxide through radicular dentin. J Endod 1993;19:136-140.

19. Aktner BO, Bilkay U. Smear layer removal with different concentrations of EDTA-ethylenediamine mixtures. J Endod 1993;19:228-231.

20. Yamashita JC, Tanomaru Filho M, Leonardo MR, Rossi MA, Silva LA. Scanning electron microscopic study of the cleaning ability of chlorhexidine as a root-canal irrigant. Int Endod J 2003;36:391394. 